\title{
Research on the Training Mode of the Innovative Talents in Universities
}

\author{
Han Ziyang \\ School of Information \& Control engineering \\ Shenyang Jianzhu University \\ Shenyang, China
}

\author{
Wang Shoujin \\ School of Information \& Control engineering \\ Shenyang Jianzhu University \\ Shenyang, China
}

\begin{abstract}
In the final analysis, the competition among the modern society is the talent competition, the talented person is the importance of the country, and the analysis of the current international situation, it is necessary for our country to have a creative and innovative talents. The important task of innovation and entrepreneurship training is to fall in the major universities of our country, so it is very important to construct a new model. In the new mode, to cultivate students' innovation ability as the goal, through the cultivation and guidance of the individual, to open up a path for the students. In this paper, the main content of the training mode of innovative talents in Colleges and universities is to promote the cultivation of innovative talents in Colleges and universities in our country, and contribute to the cultivation of talents in China.
\end{abstract}

Keywords-Individual Talents; Innovation and Entrepreneurship Talents; University Personnel Training Mode

\section{INTRODUCTION}

Innovation is the driving force for the development, and it is essential for a country, so the cultivation of innovative talents is the only way to realize the great rejuvenation of the Chinese nation. And the cultivation of innovative talents not only needs the support of all aspects of the country, but also the training mode, only in this way can we ensure the training of talents. University personnel training is the main means of higher education in our country, so that the important place to cultivate talents, so that innovation and entrepreneurship education in Colleges and universities can guarantee the quality of talents, in the new era, we must speed up the reform of education system, create a new talent training mode, and ensure the continuous emission of personalized talent.

\section{INTRODUCTION TO THE TRAINING MODE OF INNOVATION AND ENTREPRENEURSHIP}

\section{A. Connotation of Innovation and Entrepreneurship}

The traditional education in our country is lack of the cultivation of the innovation ability and the innovation consciousness. But the education mode has been deeply rooted in our country's higher education. To make a change, we must take strong measures to deepen the reform of education system. Innovation and entrepreneurship education for the training of personnel, the focus is on the ability to innovate, in the premise of ensuring innovation ability to actively guide students to try, so as to continuously inject new blood into various industries in our country, so as to promote the rapid development of various industries.

Innovation and entrepreneurship education for the training of personnel, the focus is on the ability to innovate, in the premise of ensuring innovation ability to actively guide students to try, so as to continuously inject new blood into various industries in our country, so as to promote the rapid development of various industries. At the same time in the process of work with the spirit of being able to endure hardship, to have the courage to explore and not afraid of difficulties, and with all aspects of skills, so that the entire development of the talent is the goal of innovation and entrepreneurship education.

\section{B. Connotation of Innovation and Entrepreneurship Training Mode}

A perfect talent training mode must be from the concept, method, system and evaluation system of the four aspects, to achieve mutual combination, mutual promotion, for the ultimate goal of the training of personnel. For innovation and entrepreneurial talent training mode, the goal is to cultivate the personality of the current situation of the individual, in the teaching idea to the students' innovation ability as the center, pay attention to the students in all aspects of the establishment of a sense of innovation. To create an innovative educational atmosphere within the school, and training students in the environment can also continuous innovation consciousness, can through the success of their propaganda brothers and sisters experience to stimulate students' innovation and entrepreneurial passion, forming a model effect, so as to promote student's ability.

For innovation and entrepreneurship training mode, we should do from practical, from the teaching plan to develop and implement the specific implementation should be put in place, the reform of education and teaching system, to abandon the traditional education for talent training, and establish a new concept of talent training, which is fundamental. At the same time, we should pay attention to the construction of the evaluation system, because this is a strong guarantee for the training mode of personnel, through various evaluation system can be adjusted to the problems in the system, so as to continuously improve. 


\section{PRoblems EXISTING IN THE CULTIVATION OF INNOVATIVE TALENTS IN COLLEGES AND UNIVERSITIES IN CHINA}

\section{A. The Influence of Chinese Traditional Education Mode}

Our country's education is divided into basic education and higher education. The university is the main place of higher education. For the students, in the basic education stage, the influence of traditional education is very deep, so it is easy to lose themselves in the new education mode. Our country's basic education does not pay attention to the cultivation of students' innovative education, but it is hard to cultivate the innovation ability in higher education. So, the current college students' innovation and entrepreneurship education mainly stay in the students' career guidance, cannot form a good innovation and entrepreneurship education atmosphere, so that the traditional education is deeply rooted in the new education mode.

\section{B. The Influence of Quality Education in Innovation and Entrepreneurship Education}

Innovative talents not only need to have the innovative consciousness, but also to achieve the comprehensive development of the students. This is a very high quality of students, but in the present form, the quality education of college students in our country is not optimistic. At present, college students have not experienced too many things, both in the mind or in dealing with the problem is very lack, and because most of them are only children, lack of team cooperation consciousness, but also may have personal and physical and mental health development of students, quality education in the new teaching mode cannot be ignored, so that quality education should be combined to promote the cultivation of talents.

\section{Lack of Innovation in Teaching Training}

Innovation and entrepreneurship education flagship innovation, so that in the teaching and training, we must implement the idea, whether it is from the teaching method or from the system management, cannot remain unchanged, to continue to innovate. The current teaching mode, still use more traditional teaching methods, to teachers, the lack of cultivation of independent thinking of students, practical ability and innovation ability, in the exam arrangement, still use the way of examination oriented education, this kind of exam is just the investigation for students to master knowledge and innovative ability of students so not to lose our study, the innovation ability is the live training goal the significance of students to cope with the examination, candidates must write back the hard way, the same is the personality of the students thinking and ability to suppress, is difficult to improve.

\section{Management System Cannot be Updated in Time}

Management system is the guarantee of personnel training, only the management system and personnel training objectives, to play a role, and if out of line, it will play the opposite effect. At this stage, we should innovate and develop talents, so we must adapt to the management system, the management system cannot be updated, it will seriously hinder the realization of our education objectives, so that personnel training cannot be guaranteed. The traditional management system has too many constraints, pay attention to students' discipline requirements, but also the students' learning focus on the classroom, ignoring the importance of social innovation and entrepreneurship training, because it is necessary to have a long-term social awareness, can be from the community to seize the opportunity, which is not out of the classroom, students must go to experience.

\section{THE CONSTRUCTION OF THE MODEL OF PERSONALIZED INNOVATION AND ENTREPRENEURSHIP}

\section{A. Good at Absorbing Foreign Successful Teaching Experience}

We cannot be too blind in the process of building the talent training mode, we should learn to learn from, for foreign more successful teaching mode, we can analyze, get inspiration, which is conducive to find suitable for China's education development model. We can learn from the developed countries such as the United States and Japan.

In terms of innovation and entrepreneurship curriculum reform, the United States colleges and universities according to the school's professional focus on the creation of a number of specialized courses, in the course of the teaching process is mainly a successful venture case analysis, from the case analysis to find the students to be successful, so that students can find the direction of the improvement, which is very important for new talent. And the British university in innovation and entrepreneurship education in the formation of a more level of personnel training system for different students' characteristics of their training, to ensure the full play of the inherent potential of students, so that it is fully developed, after this mode of training, for all walks of life to transport a large number of new talent, provide a solid force.

\section{B. Development of Students' Potential.}

Each person is different, have their own good place, so before the training of personnel, to the students to determine the direction of the ability, through personalized education, guide students to find their own strengths, develop their life development plan, so that students have their own development goals, so that students can be fully developed. On the one hand, students should choose their own interests, and they can choose their favorite areas. At the same time, the teacher can also carry out professional guidance to ensure that students choose their own. In this regard, the school can take two ways, on the one hand, the students can better understand themselves through some tests. On the other hand, the teacher makes a suggestion to the students. Making development goals and plans are helpful to improve the students' learning process and to promote the students' training objectives.

\section{Focus on Students' Comprehensive Development}

Innovation and entrepreneurship for students in all aspects of the ability to have a very high demand, not just stay in the cultivation of innovative ability, a successful entrepreneur must master the knowledge of various disciplines, but also have good communication skills and teamwork ability, etc., so that in the process of training students should pay attention to the comprehensive 
development of students. Practice tells us that a knowledge of a discipline is bound to fail, so that in the training of personnel should pay attention to the improvement of the quality of the discipline, the cross is very important, which can cultivate students' thinking ability and thinking ability.

\section{Pay Attention to Practice Teaching and Theory Teaching}

Innovation and entrepreneurship to have more easily than ordinary people to accept the information, the ability to deal with the problem, so in the teaching process should pay attention to practical teaching, training students' ability, the scope of practice for the community, so that students in the social arena to absorb experience, for the future to better adapt to social accumulation experience. We know that in the course of the business need to have a wealth of social experience, only in order to be in an invincible position in the fierce market competition, to seize a variety of business opportunities, while avoiding the exclusion of other enterprises, to maintain the normal development of enterprises. Practice teaching content and form to form with the social change, the most fundamental is to let students experience the development trend of modern society, the accumulation of experience in the society, and gradually formed a system of theory and practice of the teaching mode of the combination of theoretical knowledge, students will be promptly applied in practice, at the same time to experience this the stage for students to help the fire, this is the most important.

\section{E. Cultivate Students' Entrepreneurship Awareness, Encourage Students to Start a Business}

The ultimate goal of innovation and entrepreneurship training is to carry out entrepreneurship, innovation in various industries, and to bring a steady stream of energy, so that the students should be encouraged to carry out their own business independently. At the same time for students to explain the success of the business case for students to do guidance, to provide students with the opportunity to simulate the entrepreneurial experience, so that students can experience the hardships of the business process and the joy of the harvest, so not only can exercise students' perseverance, but also to provide students with a set of entrepreneurial experience, which is very important for students in the future. The talent we need is not just to stay in the concept of innovation, but the real attempt to try, to succeed, to make our country all walks of life to be updated and development.

\section{CONCLUSION}

The training mode of innovative talents is not only requiring us to have a clear understanding of the target of talent training at this stage, to recognize the essence of talent, but also to analyze the current situation of university personnel training, to solve the problems that need to be solved. In the process of building the talent training mode, we should learn from foreign experience, combine the current situation of our country, try to find a new teaching mode, which is suitable for our country. We should be good at developing the students' potential.

\section{REFERENCES}

[1] Feng Jing. On the Construction of the Cultivation Mode of Innovative Talents in Colleges and Universities [J]. Industry and Technology Forum, 2014,22:172-173.

[2] Jiang Hui, Yin Huihuang, Xu XiaoXu. Research on the Training Mode of the Innovative Talents in Universities [J]. Journal of National Academy of Education, 2015,03:27-31.

[3] Sun Qiuzhi, Tong Aiqun, Song Changqin. Research on the Innovative and Entrepreneurial Talent Training Mode of Computer Experiment Teaching in Colleges and Universities [J]. Education Teaching Forum, 2015,27:230-231.

[4] Huang Wei, Tang You, Tong Mingliang. Research on Innovation and Entrepreneurial Talent Training Mode of Private Universities Based on Regional Economic Development [J]. Journal of Heilongjiang Bayi Agricultural University, 2013,02:92-94.

[5] Jia Yanfeng, Li Yueyun, LiuLaixia. The Inherent Defects of the Current Inovation and Entrepreneurship Training Mode and the Improvement of it -- Based on the Survey of 6 Universities in Anhui Province $[\mathrm{J}]$. Innovation and Entrepreneurship Education,2013,02:55-56.

[6] Qu Qunzhen, Zhang Rui. Research on the Training Mode of the Individualized Talents Based on the Research Oriented Teaching and Exploring Study -- Taking the S Maritime College as an Example [J]. Logistics technology,2012,01:151-154.

[7] Zhou Jian. The Construction of Innovative Talents Training Mode in Colleges and Universities [J]. Journal of Yangtze University: Social Sciences,2011,12:141-143. 